\title{
Pengembangan Penilaian Proyek Pembelajaran IPA Berbasis Discovery Learning untuk Mengukur Keterampilan Pemecahan Masalah
}

\author{
Vidya Putri Sukmasari ${ }^{1} *$, Dadan Rosana ${ }^{1}$ \\ ${ }^{1}$ Program Studi Pendidikan Sains, Program Pascasarjana, Universitas Negeri Yogyakarta. \\ Jalan Colombo No. 1, Karangmalang, Yogyakarta 55281, Indonesia \\ * Corresponding Author. Email: vidya17an@gmail.com, Telp: +62274 586168 \\ Received: 16 August 2016; Revised: 30 May 2017; Accepted: 5 June 2017
}

\begin{abstract}
Abstrak
Penelitian ini bertujuan untuk mengembangkan instrumen penilaian proyek berbasis model discovery learning yang layak digunakan dan sebagai salah satu inovasi pengembangan penilaian proyek secara lebih oprasional. Penelitian ini merupakan penelitian pengembangan dengan mengintegrasikan model 4-D dengan model pengembangan instrumen nontes. Subjek uji coba yaitu peserta didik Kelas VIII SMP Muhammadiyah 3 Depok, Kabupaten Sleman. Data dalam penelitian ini diperoleh melalui: (1) penilaian berdasarkan masukan para ahli, untuk menentukan validitas isi instrumen; (2) hasil uji coba terbatas untuk menentukan reliabilitas instrumen, instrumen pengumpulan data berupa lembar observasi penilaian proyek untuk mengukur keterampilan pemecahan masalah. Instrumen penilaian proyek berbasis model discovery learning yang dikembangkan dinyatakan valid dan reliabel sehingga layak digunakan serta terbukti dapat digunakan untuk mengukur keterampilan pemecahan masalah peserta didik.
\end{abstract}

Kata Kunci: penilaian proyek, keterampilan pemecahan masalah, discovery learning, pembelajaran IPA

\section{Developing Discovery-Learning Based Natural Sciences Learning Project Assessment to Assess Problem Solving Skill}

\begin{abstract}
This research aims to develop project-based assessment instruments model discovery learning a proper use. This research is research development by integrating 4-D model with the model development of noninstrument test. The subject of the test i.e. learners Class VIII Junior High School of Muhammadiyah 3 Depok Sleman Regency. The data in this study were obtained through (1) assessment based on the input of experts, to determine the validity of the content of the instrument; (2) the limited Test Results to determine the reliability of the instrument, the instrument of data collection in the form of sheets of observation project assessment to measure problem solving skills. The instruments of project-based assessment model of discovery learning developed declared valid and reliability so that the feasibility as well as proven can be used to measure student's problem-solving skills.
\end{abstract}

Keywords: project assessment, problem-solving skills, discovery learning, learning science

How to Cite: Sukmasari, V., \& Rosana, D. (2017). Pengembangan penilaian proyek pembelajaran IPA berbasis discovery learning untuk mengukur keterampilan pemecahan masalah. Jurnal Inovasi Pendidikan IPA, 3(1), 101-110. doi:http://dx.doi.org/10.21831/jipi.v3i1.10468

Permalink/DOI: http://dx.doi.org/10.21831/jipi.v3i1.10468 


\section{PENDAHULUAN}

Sesuai dengan yang ditetapkan Badan Standar Nasional Pendidikan, bahwa Ilmu Pengetahuan Alam (IPA) berkaitan dengan cara mencari tahu tentang alam secara sistematis sehingga IPA bukan hanya penguasaan kumpulan pengetahuan yang berupa fakta-fakta, konsep-konsep, atau prinsip-prinsip saja, tetapi juga merupakan suatu proses penemuan untuk memperoleh pemahaman yang lebih mendalam.

Hewitt, Lyons, Suchok, \& Yeh (2007, p.13) mendefinisikan science atau IPA merupakan temuan kolektif manusia tentang alam, dan proses pengumpulan dan pengorganisasian pengetahuan tentang alam. Konsep IPA berhubungan dengan kehidupan sehari-hari, dan menekankan pada tema utama secara jelas sehingga memberikan informasi keterkaitan konsep. IPA merupakan suatu pendekatan yang menekankan pada proses ilmiah dalam mengkaji alam sebagai pengetahuan ilmiah dan dapat diaplikasikan dalam kehidupan sehari-hari sebagai sebuah pengalaman belajar (Trefil \& Hazen, 2000, p.12).

Dari penjelasan tersebut, dapat dikatakan bahwa kegiatan pembelajaran diharuskan berorientasi pada keaktifan peserta didik di kelas dan pembelajarannya dititikberatkan pada prosesnya, bukan pada hasil yang dicapainya. Peserta didik dituntut untuk membangun pengetahuan mereka melalui proses penemuan konsep dengan guru hanya sebagai fasilitator.

Hal ini kontras dengan proses pembelajaran saat ini, pembelajaran IPA yang dilakukan kebanyakan masih berorientasi pada hasil dan penuntasan materi pelajarannya saja tanpa melatih peserta didik untuk lebih mengembangkan keterampilan berpikirnya. Hal ini menyebabkan peserta didik merasa terbebani dengan tuntutan penuntasan materi pelajaran sehingga lemahnya salah satu keterampilan berpikir peserta didik yakni keterampilan pemecahan masalah. Hal ini dimungkinkan karena guru belum memfasilitasi peserta didik secara optimal untuk berlatih berpikir dalam memecahkan masalah tertentu.

Pendapat dikemukakan oleh Heng et al (2002, p.7) bahwa keterampilan pemecahan masalah adalah kemampuan untuk mencari solusi pada situasi yang menantang atau asing atau dari kesulitan yang tak terduga dengan carayang sistematis. Brookhart (2014, p.12) menyatakan bahwa problem solving merupakan metafora besar bagi sebagian besar tugas agar pemikiran yang lebih tinggi dan sebagian besar tugas penilaian yang menyadap pemikiran tingkat tinggi. Berikut ini merupakan urutan dalam pemecahan masalah yang dikemukakan oleh Polya (Muijs \& Reynolds, 2011, pp.152154) antara lain: Understanding and representing the problem, selecting orplanning the resolution, execute the plan, dan Evaluing the result.

Keterampilan pemecahan masalah merupakan salah satu keterampilan tingkat tinggi yang harus dikuasai peserta didik untuk dapat mengikuti perkembangan jaman. Proses pemecahan masalah cocok untuk diterapkan dalam pembelajaran IPA karena dapat meningkatan kemampuan berpikir peserta didik secara logis, kritis, kreatif dan inovatif. Selain itu, keterampilan pemecahan masalah memberikan kesempatan kepada siswa untuk mengembangkan kemampuan berpikir dalam memecahkan masalah melalui pengkonstruksian pengetahuan yang dimiliki siswa secara mandiri dengan memanfaatkan berbagai sumber belajar sehingga pemahaman materi menjadi lebih mendalam dan pembelajaran men-jadi lebih bermakna (Tivani \& Paidi, 2016, p.43). Problem solving skills atau keterampilan pemecahan masalah merupakan salah satu keterampilan tingkat tinggi yang harus dikuasai peserta didik untuk dapat mengikuti perkembangan jaman. Beberapa permasalahan global tersebut sejatinya sangat erat kaitannya dengan pembekalan pembelajaran yang bermanfaat bagi masa depan peserta didik. Beberapa aspek problem solving yakni mencakup kemampuan peserta didik dalam memahami permasalahan, mendefinisikan permasalahan, merumuskan/merencanakan solusi alternatif, menerapkan strategi/solusi pemecahan, dan evaluasi hasil pemecahan masalah yang telah dilakukannya.

Permasalahan dalam pembelajaran IPA yang masih ditemukan di lapangan adalah lemahnya keterampilan pemecahan masalah pada peserta didik, khususnya pada kompetensi dasar yang mencakup pengembangan soal-soal yang kontekstual. Kendala yang muncul adalah kesulitan peserta didik dalam menemukan permalahan yang dikehendaki guru untuk dipecahkan. Peserta didik merasa kesulitan dalam mendefinisikan permasalahan terutama pada soal-soal pada materi yang bersifat abstrak

Salah satu komponen lain yang terpenting dalam pembelajaran adalah ketersediaan instrumen penilaian pembelajaran untuk mengukur keberhasilan pembelajaran yang telah dilakukan. 
Untuk mengukur ketercapaian proses pembelajaran IPA, diperlukan suatu instrumen penilaian yang sesuai. Penilaian (assessement) sejatinya adalah kegiatan untuk melakukan pengukuran dan pembandingan terhadap hasil belajar peserta didik. Kegiatan penilaian akan memudahkan guru dalam menentukan tindak lanjut yang tepat, sehingga diperlukan instrumen yang valid dengan disertai kriteria yang sesuai dan jelas untuk menghasilkan penilaian yang akurat mengenai kemampuan peserta didik, sedangkan penilaian yang kebanyakan dilakukan hanya tertuju kepada hasilnya (sebatas pemahaman konsep ranah pengetahuan). Kurikulum 2013 menghendaki penilaian pembelajaran secara autentik. Mueller (2006, p.2) menyatakan bahwa penilaian otentik (authentic assessment) merupakan suatu bentuk penilaian yang menuntut peserta didik melakukan tugas dunia nyata dan menunjukkan esensi penerapan pengetahuan dan keterampilan.

Moon, Brighton, \& Callahan (2005, p.120) pelaksanaan penilaian otentik memiliki karakteristik antara lain fokus pada materi yang penting (ide-ide atau konsep besar); merupakan penilaian yang mendalam; mudah dilakukan di kelas atau di lingkungan sekolah; menekankan pada kualitas produk atau kinerja dari pada jawaban tunggal; dapat mengembangkan kekuatan dan penguasaan konsep siswa; memiliki kriteria yang dipahami antara guru dan siswa sebelum penilaian dimulai; menyediakan banyak cara yang memungkinkan siswa dapat menunjukkan kemampuannya sebagai hasil belajar, dan pemberian skor penilaian didasarkan pada esensi tugas.

Suatu penilaian otentik melibatkan tugastugas bagi para siswa dan sebuah kriteria atau rubrik penilaian. George Mason University (Callison, 1998, p.2) telah mendaftar karakteristik kinerja siswa yang harus dipertimbangkan dalam penilaian otentik:(a) membangun respon; (b) tingkat berpikir yang lebih tinggi (keterampilan dalam analisis, sintesis, dan evaluasi); (c) keotentikan; (d) integratif; (e) proses dan produk; (f) kedalaman penilaian kinerja membangun dari waktu ke waktu dengan berbagai kegiatan untuk mencerminkan pertumbuhan, kedewasaan, dan kedalaman, yang mengarah ke penguasaan strategi dan proses untuk memecahkan masalah di daerah tertentu dengan asumsi bahwa keterampilan ini akan ditransfer untuk memecahkan masalah lain.

Kecenderungan dewasa ini adalah kurangnya sosialisasi dan minimnya contoh instrumen penilaian secara autentik sebagaimana yang diharapkan pada pembelajaran di kurikulum 2013. Kebanyakan guru kesulitan menyusun instrumen penilaian autentik. Kesulitan guru dalam mengimbangi perubahan bentuk penilaian ini berdampak pada kualitas penilaian yang dilakukan oleh guru itu sendiri.

Sistem penilaian yang dilakukan baik oleh guru, sekolah dan bahkan oleh pemerintah cenderung masih menggunakan penilaian tradisional, yaitu memberikan sejumlah soal dengan jawaban pendek, isian atau pertanyaan pilihan ganda dan menilai sejumlah tugas terbatas yang kurang sesuai dengan apa yang dikerjakan selama proses pembelajaran berlangsung. Selain itu, materi IPA memiliki karakteristik yang berbeda-beda sehingga tidak semua materi IPA dapat dinilai dengan cara yang sama. Dengan demikian, instrumen penilaian yang digunakan tentunya juga berbeda. Permasalahan yang muncul di sini adalah masih terbatasnya produkproduk instrumen penilaian yang dikembangkan sebagai penilaian yang terstandar dan sesuai untuk digunakan.

Menurut Stiggins (1994, p.67), salah satu hasil penilaian yang layak untuk dijadikan dasar dalam menentukan jenis penilaian autentik adalah keterampilan memecahkan masalah (keterampilan pemecahan masalah). Keterampilan pemecahan masalah peserta didik ini terdiri atas beberapa aspek yang mendasar. Beberapa aspek dasar dari problem solving pada peserta didik tentunya hanya dapat diukur dengan menggunakan jenis instrumen tertentu.Salah satu jenis tugas yang dapat diberikan oleh peserta didik secara autentik adalah dengan memberikan penugasan berupa proyek.

Penjelasan Dewey dalam Akinoglu (2008, p.2) menjelaskan bahwa salah satu kegiatan pendidikan yang paling spektakuler dan efektif memungkinkan belajar dengan melakukan dan pembelajaran aktif berbasis inkuiri dalam pendidikan sains adalah kegiatan proyek. Terlihat bahwa peserta didik dapat belajar memecahkan suatu permasalahan sendiri setelah diterapkannya kegiatan proyek dalam pembelajaran di sekolah milik Dewey. Hal ini yang mendasari bahwa penilaian berbasis proyek atau penilaian proyek merupakan salah satu penilaian yang memacu peserta didik keranah berpikir tingkat tinggi salah satunya yakni keterampilan pemecahan masalah.

Menurut Majid (2014, p.63) menjelaskan bahwa penilaian proyek merupakan penyelesaian tugas peserta didik berupa investigasi yang 
dilakukan dimulai dari perencanaan, pengumpulan data, pengorganisasian, pengolahan, analisis, dan penyajian data. Tugas proyek menurut Shariff, Johan, \& Jamil (2013, p.753) dapat menanamkan dan mengembangkan kepemimpinan, komunikasi, kerja sama, dan keterampilan pemecahan masalah. Ada 3 (tiga) hal yang perlu dipertimbangkan dalam menilai proyek yakni: (1) kemampuan pengelolaan; (2) relevansi; dan (3) keaslian. Sedangkan beberapa kegiatan pembelajaran yang dilakukan dalam penilaian proyek yakni: Perencanaan, pelaksanaan yang meliputi penyusunan desain, pengumpulan data, analisis data, dan penyiapan laporan tertulis, serta pembuatan laporan

Komponen penting lain dalam penyediaan wahana belajar peserta didik adalah dalam penggunaan model pembelajaran. Penggunaan model yang bervariasi dapat mendukung keberhasilan belajar peserta didik. Salah satu model pembelajaran yang sesuai untuk digunakan dalam pembelajaran IPA adalah model discovery learning. Penjelasan Dewey dalam Castronova (2002, p.1) menyatakan bahwa model discovery learning didefinisikan sebagai proses pembelajaran yang terjadi bila pelajar tidak disajikan dengan pelajaran dalam bentuk finalnya, tetapi diharapkan peserta didik dapat mengorganisasikan sendiri konsep yang harus dipahami. Di dalam strategi penemuan, peserta didik belajar menguasai salah satu metode ilmiah yang dapat dikembangkannya sendiri, sehingga peserta didik dapat belajar berpikir analisis dan mencoba memecahkan masalah yang dihadapi sendiri di kehidupan sehari-hari.

Konsep dasar dari discovery learning menurut Mandrin \& Preckel (2009) adalah bahwa guru harus memfasilitasi pembelajaran yang memungkinkan peserta didik untuk menemukan hasil yang telah ditentukan sesuai dengan tingkat pembelajaran yang sesuai dengan standar kurikulum (Champine, Duffy, \& Perkins, 2009). Sejalan dengan pendapat Shalin (2012, p.2) yang menyatakan bahwa dalam kegitan pembelajaran menggunakan Discovery learning siswa secara aktif mencari/menemukan sendiri, yang dapat dilakukan dalam pedoman/rangka tugas pendidikan serta interaksi pendidikan dengan lingkungan online akademik.

Pada pelaksanaan pembelajaran discovery learning, kegiatan yang dilakukan guru secara bertahap yaitu: Stimulation (stimulasi/pemberian rangsangan), pada tahap ini pelajar dihadapkan pada sesuatu yang menimbulkan kebingungannya, kemudian dilanjutkan untuk tidak memberi generalisasi, agar timbul keinginan untuk menyelidiki sendiri. Problem statement (pernyataan/identifikasi masalah) langkah selanjutya adalah guru memberi kesempatan kepada peserta didik untuk mengidentifikasi sebanyak mungkin agenda-agenda masalah yang relevan dengan kemudian salah satunya dipilih dan dirumuskan dalam bentuk hipotesis (jawaban sementara atas pertanyaan masalah). Data collection (Pengumpulan Data), ketika eksplorasi berlangsung guru juga memberi kesempatan kepada para peserta didik untuk mengumpulkan informasi sebanyak-banyaknya yang relevan untuk membuktikan benar atau tidaknya hipotesis. Data Processing (Pengolahan Data), Pada tahap ini peserta didik melakukan pemeriksaan secara cermat untuk membuktikan benar atau tidaknya hipotesis yang ditetapkan tadi dengan temuan alternatif, dihubungkan dengan hasil data processing. Generalization (menarik kesimpulan/generalisasi), Tahap generalisasi/ menarik kesimpulan adalah proses menarik sebuah kesimpulan yang dapat dijadikan prinsip umum dan berlaku untuk semua kejadian atau masalah yang sama, dengan memperhatikan hasil verifikasi.

Karakteristik materi IPA yang diajarkan di sekolah juga mempengaruhi dalam penentuan baik metode, pendekatan, sampai dengan jenis tugas yang diberikan sebagai dasar untuk penilaian.Salah satu materi IPA yang bersifat faktual dan observabel adalah materi optic pada mata manusia. Materi optik pada mata manusia merupakan materi yang diajarkan di kelas VIII pada kurikulum 2013.

Pada pembelajaran materi optik pada mata manusia memungkinkan dilakukannya suatu kegiatan yang dapat mengarahkan siswa pada proses pemecahan suatu masalah. Selain itu, Materi optik pada mata manusia dipilih karena dapat dipandang dari segi biologis maupun secara fisis di mana kedua aspek ini merupakan karakteristik dari materi IPA.Materi ini merupakan materi yang sangat dekat dengan lingkungan peserta didik. Pada materi ini memuat beberapa konsep yang bermuara pada aplikasi di kehidupan nyata.Pada pembelajaran IPA dengan materi ini memungkinkan digunakan sebagai dasar pembuatan tugas proyek untuk melatih keterampilan problem solving peserta didik di kelas VIII SMP. Mengacu pada beberapa permasalahan tersebut, maka peneliti berusaha mengembangkan penilaian proyek dalam pembelajaran berbasis discovery learning untuk mengukurproblem solving peserta didik 
pada materi optik pada mata manusia untuk peserta didik SMP.

\section{METODE}

Jenis penelitian yang digunakan dalam penelitian ini merupakan penelitian pengembangan atau Research and Development (R \& D). Research and Development adalah model penelitian yang digunakan untuk menghasilkan produk tertentu dan menguji keefektifan produk (Sugiyono, 2012, p.407). Produk yang dimaksud dalam penelitian ini adalah penilaian proyek dalam pembelajaran IPA dengan model discovery learning untuk meningkatkan keterampilan pemecahan masalah peserta didik SMP kelas VIII pada materi cahaya dan indera penglihatan manusia.

Uji coba terbatas dilaksanakan di SMP Muhammadiyah 3 Depok kelas VIII C Yogyakarta dari tanggal 11-18 Februari 2016. Uji coba lapangan luas dilaksanakan SMP Muhammadiyah 3 Depok kelas VIIID Yogyakarta dari tanggal 23 Februari - 3 Maret 2016.

Subjek uji coba produk perangkat pembelajaran IPA adalah siswa SMP kelas VIII semester genap tahun pelajaran 2015/2016. Subjek coba dipilih secara random dan dibagi menjadi dua yaitu subjek uji coba terbatas dan uji coba lapangan luas.Subjek uji coba terbatas menggunakan kelas VIII C SMP Muhammadiyah 3 Depok kelas VIII C dengan jumlah 9 siswa. Subjek uji coba lapangan luas menggunakan VIII D SMP Muhammadiyah 3 Depok kelas VIII C berjumlah 33 siswa.

Model pengembangan yang digunakan dalam penelitian ini yaitu mengintegrasikan model 4D dengan model pengembangan instrumen non tes. Model pengembangan 4D memiliki langkah-langkah: (1) define, (2) design, (3) develop, (4) desseminate, sedangkan model pengembangan instrument nontes memiliki 10 langkah sebagai berikut: (1) menentukan spesifikasi instrumen, (2) menulis instrumen, (3) menentukan skala instrumen, (4) menentukan sistem penskoran, (5) mentelaah instrumen, (6) melakukan ujicoba, (7) menganalisis instrumen, (8) merakit instrumen, (9) melaksanakan pengukuran, (10) menafsirkan hasil pengukuran.

Pertama, studi pendahuluan.Pada tahap studi pendahuluan terdiri atas 3 tahapan yakni analisis peserta didik, analisis guru, dan analisis materi. Kegiatan ini dilakukan untuk mengumpulkan informasi, menganalisis kebutuhan, mereview literatur, menganalisis siswa, dan mengidentifikasi faktor-faktor yang menimbulkan permasalahan sehingga diperlukan pengembangan model perangkat baru.Studi pendahuluan pada penelitian ini meliputi studi lapangan dan studi pustaka. Studi lapangan menggunakan metode wawancara dengan guru IPA di sekolah. Studi pustaka dilakukan dengan mengkaji kurikulum yang sedang berlaku dan hasil-hasil penelitian yang relevan dengan pengembangan instrument penilaian proyek untuk mengukur keterampilan pemecahan masalahsiswa pada pembelajaran IPA berbasis discovery learning.

Kedua, menyusun spesifikasi instrumen. Pada tahap ini meliputi kegiatan memilih bentuk instrument yakni lembar observasi, kemudian menentukan indikator yang dipilih dari aspekaspek keterampilan pemecahan masalah, dan membuat kisi-kisi instrumen.

Ketiga, menulis instrumen. Penulisan instrumendidasarkan pada kisi-kisi yang telah dibuat, selanjutnya disusun butir pernyataan. Penulisan instrumen mempertimbangkan aspek materi, konstruksi dan bahasa yang digunakan agar penggunaan instrumen ini mudah memahami dan sesuai dalam memberikan penilaian. Keempat, menentukan skala instrumen. Skala instrumen yang digunakan dalam pengembangan instrumen ini berupa skala 1 sampai dengan 4. Kelima, menentukan sistem penskoran dan petunjuk penskoran. Sistem penskoran yang digunakan dalam penelitian ini adalah skor perolehan yang mengacu pada skala yang digunakan yaitu skala 1 sampai 5 berdasarkan kemunculan pilihan hasil pengamatan yang tersedia untuk masing-masing butir yang diberikan oleh observer.

Keenam, telaah instrumen. Telaah instrumen ini dilakukan oleh ahli yang sesuai dengan bidang instrumen yang dikembangkan. Ahli di bidang materi yaitupengajar di program studi pendidikan IPA. Ahli ini akan mencermati dan memberikan masukan mengenai ketercakupan indikator proyek peserta didik kedalam butirbutir instrumen yang telah disusun. Ahli di bidang pengukuran dan pengembangan instrumen pendidikan mencermati dan memberi masukan mengenai substansi, konstruk dan bahasa dalam instrumen yang dikembangkan.

Ketujuh, uji coba. Setelah mendapatkan saran dan masukan dari para ahli, peneliti melakukan perbaikan-perbaikan sesuai dengan masukan yang ada. Selanjutnya instrumen angket yang telah diperbaiki digunakan untuk uji coba. Uji coba ini bertujuan untuk menentukan reliabilitas instrumen yang dikembangkan. Kedelapan, analisis uji coba. Hasil uji coba 
lapangan dianalisis untuk menentukan reliabilitas instrumen. Instrumen akan dihitung koefisien reliabilitasnya menggunakan interrater reliability.

Kesembilan, merakit instrumen. Dari hasil analisis uji coba, perhitungan karakteristik instrumen didapatkan butir-butir yang baik, butir-butir yang perlu direvisi. Butir-butir yang baik dan yang telah direvisi akan dirakit kembali menjadi bentuk instrumen yang utuh. Butir-butir ini akan menjadi produk akhir dari penelitian pengembangan ini. Kesepuluh, melakukan pengukuran.Pengukuran ini dilakukan setelah instrumen yang dikembangkan telah diuji coba dan direvisi.Pengukuran ini bertujuan untuk mengukur keterampilan pemecahan masalah peserta didik dengan menggunakan instrumen penilaian proyek yang telah dikembangkan.

Kesebelas, penafsiran hasil pengukuran. Hasil pengukuran berupa skor.Untuk menafsirkan hasil pengukuran diperlukan suatu kriteria. Kriteria yang digunakan tergantung pada skala dan jumlah butir yang digunakan. Keduabelas, diseminasi. Proses diseminasi dalam penelitian ini dilakukan dengan menyerahkan produk kepada guru IPA SMP.

\section{Data, Instrumen, dan Teknik Pengumpulan Data}

Teknik pengumpulan data merupakan langkah yang paling utama dalam penelitian, karena tujuan utama penelitian adalah memperoleh data. Dengan demikian, teknik pengumpulan data adalah cara yang dilakukan untuk memperoleh data dalam penelitian. Teknik yang digunakan dalam penelitian ini adalah teknik wawancara dan nontes.

Wawancara digunakan pada penelitian awal untuk memperoleh data awal yang diperlukan.Instrumen yang digunakan untuk wawancara adalah lembar pedoman wawancara. Teknik non tes digunakan untuk memvalidasi instrumen penilaian yang dikembangkan. Instrumen yang digunakan adalah lembar validasi dan teknik nontes digunakan untuk mengukur keterampilan pemecahan masalah peserta didik. Instrumen yang digunakan adalah lembar observasi berupa instrumen penilaian proyek yang dikembangkan.

Instrumen yang digunakan dalam pengambilan data yakni pedoman wawancara, lembar observasi, dan angket. Pedoman wawancara pada penelitian ini berupa pertanyaan-pertanyaan tertulis tentang pembelajaran dan penilaian IPA SMP Kurikulum 2013 di Yogyakarta. Pertanyaan disusun berdasarkan aspek SKL, standar proses, standar penilaian, dan implementasi Kurikulum 2013. Lembar observasi yang digunakan saat uji coba lapangan bertujuan menilai proyek keterampilan pemecahan masalah peserta didik. Kisi-kisi penilaian proyek keterampilan pemecahan masalah peserta didik. Lembar angket digunakan untuk memperoleh data pada saatvalidasi produk hasil pengembanga. Kisikisi untuk validasi produk hasil pengembangan.

Teknik analisis data pada penelitian ini adalah analisis validasi isi secara deskriptif dan kuantitatif, analisis instrument penilaian hasil pengembangan setelah diuji coba, dan analisis Hasil Observasi Keterampilan pemecahan masalah. Analisis kuantitatif menggunakana nalisis V'aiken dalam Azwar (2014, p.113) dengan rumus sebagai berikut.

$$
\mathrm{V}=\frac{\Sigma \mathrm{s}}{\mathrm{n}(\mathrm{c}-1)}
$$

Keterangan

$\mathrm{s}: \mathrm{r}-\mathrm{lo}$

n: Jumlah panel penilai

lo: Angka penilaian validitas terendah

c: Angka penilaian validitas tertinggi

r: Angka yang diberikan oleh seorang penilai

Rentang angka $\mathrm{V}$ yang diperoleh adalah 0 sampai dengan 1,00 . Item yang memiliki validitas isi baik dan mendukung validasi isi secara keseluruhan adalah yang memiliki koefisien $\mathrm{V}$ tinggi.

Analisis instrumen penilaian hasil pengembangan setelah diuji coba yaitu mencari reliabilitas. Reliabilitas diperoleh menggunakan analisis inter-rater. Perhitungan reliabilitas instrumen penilaian penilaian proyek dilakukan dengan uji koefisien korelasi antar kelas (interclass correlation coeffisiensts/ICC) dengan bantuan SPSS seri 20.0.

Analisis keterampilan pemecahan masalah peserta didik dihitung dengan menjumlahkan skor dengan menggunakan rumus

$$
N=\frac{\sum X}{n}
$$

Keterangan:

$N$ : Nilai keterampilan pemecahan masalah peserta didik

$\sum \mathrm{X}$ : Jumlah skor maksimum

$n$ : Jumlah item

Selanjutnya mengkonversi skor menggunakan kategori pada Tabel 1. Kepraktisan instrumen penilaian yang dikembangkan diperoleh dari angket respon guru dan observer terhadap instrumen penilaian yang dikembangkan. Menjumlahkan skor angket respon guru dan observer terhadap instrumen penilaian proyek 
keterampilan pemecahan masalah dengan menggunakan persamaan berikut.

Tabel 1. Kategorisasi Skor Penilaian

Keterampilan pemecahan masalah

\begin{tabular}{cccc}
\hline No. & \multicolumn{1}{c}{ Rentang Skor } & Nilai & Kategori \\
\hline 1. & $\mathrm{X} \geq \mathrm{Yi}+1 . \mathrm{SBx}$ & $\mathrm{A}$ & Sangat Baik \\
2. & $\mathrm{Yi}+1 . \mathrm{SBx}>\mathrm{X} \geq \mathrm{Yi}$ & $\mathrm{B}$ & Baik \\
3. & $\mathrm{Yi}>\mathrm{X} \geq \mathrm{Yi}-1 . \mathrm{SBx}$ & $\mathrm{C}$ & Cukup \\
4. & $\mathrm{X}<\mathrm{Yi}-1 . \mathrm{SBx}$ & $\mathrm{D}$ & Kurang \\
\hline
\end{tabular}

(Mardapi, 2008, p.123)

$$
A=\frac{\sum X}{n} x 100 \%
$$

Keterangan:

$A=$ Skor angket respon

$\sum X=$ Jumlah skor maksimum

$n=$ Jumlah item pernyataan angket

Kemudian mengkonversi persentase menjadi kategori sesuai dengan Tabel 2

Tabel 2. Konversi Persentase menjadi Kategori

\begin{tabular}{ccc}
\hline No. & Persentase $(\%)$ & Kategori \\
\hline 1. & $\geq 80$ & Sangat Baik \\
2. & $>60-80$ & Baik \\
3. & $>40-60$ & Cukup \\
4. & $>20-40$ & Kurang \\
5. & $\leq 20$ & Sangat Kurang \\
\hline
\end{tabular}

(Widoyoko, 2009, p.242)

Analisis lembar keterlaksanaan pembelajaran model discovery learning dengan menggunakan Rumus

$K=\frac{\sum X}{n} \times 100 \%$

Keterangan:

$\mathrm{K}=$ Skor keterlaksanaan pembelajaran

$\sum \mathrm{X}=$ Jumlah skor maksimum

$\mathrm{n}=$ Jumlah item pernyataan keterlak-sanaan pembelajaran

Kemudian mengkonversi skor menggunakan kategorisasi pada Tabel 2.

\section{HASIL DAN PEMBAHASAN}

Hasil pengembangan produk awal pada penelitian ini adalah instrumen penilaian proyek berbasis discovery learning yang digunakan untuk mengukur keterampilan pemecahan masalah peserta didik. Instrumen terdiri atas lembar observasi penilaian proyek. Pada masing-masing instrumen terdapat 44 butir pernyataan yang terdiri atas 8 butir aspek memahami dan mendefinisikan permasalahan, 12 butir aspek merumuskan/merencanakan solusi alternatif, 12 butir aspek menentukan dan menerapkan strategi/ solusi pemecahan, serta12 butir aspek mengevaluasi. Materi yang diangkat dalam penelitian ini yaitu materi Optik pada Mata Manusia yang terdapat di Kelas VIII SMP Semester 2 mengikuti Kurikulum 2013. Penelitian ini dilakukan dalam 3 kali pertemuan.

Produk awal instrumeninstrumen penilaian proyek berbasis discovery learning terlebih dahulu divalidasi oleh para ahli. Validasi ahli dilakukan untuk mengetahui kelayakan instrumen secara teoritis. Penelitian ini melibatkan 7 orang ahli yaitu 1 dosen ahli materi, 1 dosen ahli evaluasi, dan 5 praktisi yaitu guru yang aktif mengajar IPA Kelas VIII SMP. Butir instrumen penilaian divalidasi berdasarkan aspek substansi, konstruksi dan bahasa.Skor hasil penilaian dari 7 orang validator kemudian dianalisis menggunakan formula Aiken's untuk menghitung contenct validity coefficient $(\mathrm{V})$. Selanjutnya angka V Aiken's dikonfirmasi dengan batas angka pada tabel V Aiken's untuk jumlah kategori penilaian 4 , dengan 7 orang penilai yaitu 0,78 . Hasil perhitungan nilai $\mathrm{V}$ dari ke-6 validator pada setiap butirnya rata-rata memiliki kriteria baik. Nilai V antara 0,86 Hingga 1 membuktikan bahwa setiap butir mempunyai validitas yang baik (Aiken, 1985).

Hasil validasi didapatkan melalui instrumen validasi dan butir soal yang telah dibuat dari validasi ahli dibagi menjadi tiga, yaitu: (1) valid tanpa revisi, (2) valid dengan revisi, dan (3) tidak valid. Penilaian validitas draf awal dapat dilihat melalui rekapitulasi yang terdapat pada Tabel 3.

Tabel 3. Rekapitulasi Hasil Validasi Ahli

\begin{tabular}{llccc}
\hline \multirow{2}{*}{ No. } & \multirow{2}{*}{ Validator } & \multicolumn{3}{c}{ Nomor Butir Pernyataan } \\
\cline { 2 - 5 } & Valid Tanpa Revisi & Valid dengan revisi & Tidak Valid \\
\hline 1. & Ahli & - & Semua Butir & - \\
& Jumlah & - & 44 butir & - \\
2. & Guru & $6 \mathrm{a}, 6 \mathrm{~b}, 7 \mathrm{a}, 8 \mathrm{a}, 8 \mathrm{~b}, 8 \mathrm{~d}, 10 \mathrm{a}, 11 \mathrm{a}$, & $1 \mathrm{a}, 1 \mathrm{~b}, 1 \mathrm{c}, 1 \mathrm{~d}, 2 \mathrm{a}, 2 \mathrm{~b}, 2 \mathrm{c}, 2 \mathrm{~d}, 3 \mathrm{a}, 3 \mathrm{~b}, 3 \mathrm{c}, 3 \mathrm{~d}, 4 \mathrm{a}, 4 \mathrm{~b}$, & $9 \mathrm{a}, 9 \mathrm{~b}, 9 \mathrm{c}, 9 \mathrm{~d}$ \\
& $11 \mathrm{c}$ & $4 \mathrm{c}, 4 \mathrm{~d}, 5 \mathrm{a}, 5 \mathrm{~b}, 5 \mathrm{c}, 5 \mathrm{~d}, 6 \mathrm{c}, 6 \mathrm{~d}, 7 \mathrm{~b}, 7 \mathrm{c}, 7 \mathrm{~d}, 8 \mathrm{c}$, \\
\\
& & & $10 \mathrm{~b}, 10 \mathrm{c}, 10 \mathrm{~d}, 11 \mathrm{~b}, 11 \mathrm{~d}$ & \\
& & & 31 butir & 4 butir \\
\hline
\end{tabular}


Saran ketika terjadi revisi dibagi menjadi 8 macam, terkumpul masukan dari dosen ahli, dan pendidik. Kedelapan saran tersebut adalah: (1) perbaikan pada kompetensi dasar yang dipakai, (2) perbaikan pada penulisan beberapa kata yang kurang sesuai dengan EYD, (3) perbaikan pada pemilihan bahasa yang kurang efektif (4) perbaikan butir pernyataan pada lembar penilaian proyek mengenai urutan butir penilaian pada beberapa indikator keterampilan pemecahan masalah, (5) perbaikan pada pernyataan butir yang tidak dirumuskan secara singkat, jelas, dan tegas, (6) perbaikan pada butir pernyataan yang mengandung pernyataan yang tidak diperlukan, (7) perbaikan pada rubrik penskoran yang kurang jelas, dan (8) perbaikan pada butir pernyataan yang masih mengalami perulangan. Salah satu masukan dari ahli yakni mengenai penghapusan 4 butir yakni nomor 9a,9b, 9c, dan 9d. Penghapusan ini dilakukan karena pertimbangan bahwa butir tersebut kurang sesuai untuk ditampilkan dalam instrumen hasil pengembangan. Seluruh masukan dari validator digunakan sebagai dasar perbaikan produk untuk dapat digunakan pada tahap selanjutnya yaitu uji coba terbatas.

Reliabilitas instrumen penilaian proyek diperoleh dari uji coba kelompok kecil.Uji coba dilakukan pada kelas VIII C SMP Muhammadiyah 3 Depok Sleman.Uji coba dilakukan selama 3 kali pertemuan. Perhitungan reliabilitas instrumen penilaian hasil pengembangan dilakukan pada hasil penilaian akhir oleh 5 orang penilai/ rater disetiap kegiatan proyek yang dikerjakan 9 siswa dari 3 kali pertemuan. Penilaian keterampilan pemecahan masalah dilakukan pada hasil pengamatan dan hasil kinerja proyek siswa pada LKPD selama melakukan pembelajaran berbasis discovery learning.Penilai memberikan tanda checklist pada butir yang muncul pada hasil kerja masing-masing siswa berdasarkan instrument yang telah disediakan.
Analisis instrumen penilaian hasil pengembangan setelah di uji coba yaitu mencari reliabilitas. Reliabilitas diperoleh menggunakan analisis inter-rater. Perhitungan reliabilitas instrumen penilaian penilaian proyek dilakukan dengan uji koefisien korelasi antar kelas (interclass correlation coeffisiensts/ICC) dengan bantuan SPSS seri 20.0. Nilai koefisien alpha pada setiap pertemuan menunjukkan bahwa nilai reliabilitas lebih dari 0,7 yang berarti instrmen dapat dikatakan baik dan reliabel (Widoyoko, 2014) sebagaimana disajikan dalam Tabel 3.

Tabel 4. Nilai Koefisien Alpha pada Setiap Pertemuan

\begin{tabular}{cc}
\hline Pertemuan ke- & Nilai Koefisien Alpha Cornbach \\
\hline 1 & 0.87 \\
2 & 0.811 \\
3 & 0.89 \\
\hline
\end{tabular}

Instrumen yang telah di uji coba terbatas, kemudian direvisi.Kegiatan Revisi yang kedua merupakan tahapan perbaikan instrumen penilaian proyek untuk mengukur keterampilan pemecahan masalahberdasarkan kendala yang dijumpai ketika penghgunaan produk pada uji coba. Hasil revisi ini digunakan untuk menghasilkan produk instrumen penilaian proyek untuk mengukur keterampilan pemecahan masalah pembelajaran IPA dengan moedel discovery learning materi optik pada mata manusia yang layak untuk digunakan sebagai produk akhir penelitian ini. Kegiatan revisi yang kedua dilakukan berdasarkan pertimbangan yang diputuskan yaitu: (a) mempersingkat waktu persiapan pengerjaan proyek, dan (b) memperbaiki urutan penempatan butir pada lembar observasi penilaian proyek.

Instrumen yang telah reliable dari hasil uji coba terbatas kemudian digunakan untuk mengukur keterampilan pemecahan masalah peserta didik. Hasil penghitungan rata-rata aspek problem solving ketiga pertemuan dapat dilihat pada Tabel 5.

Tabel 5. Rata-rata Per Aspek Keterampilan pemecahan masalah

\begin{tabular}{|c|c|c|c|c|c|}
\hline \multirow[t]{2}{*}{ Aspek Science Process Skills } & \multicolumn{3}{|c|}{$\begin{array}{l}\text { Skor Total Rerata } \\
\text { Pertemuan }\end{array}$} & \multirow{2}{*}{$\begin{array}{l}\text { Rata- } \\
\text { rata }\end{array}$} & \multirow[t]{2}{*}{ Kategor } \\
\hline & 1 & 2 & 3 & & \\
\hline Memahami dan mendefinisikan permasalahan & 2.6 & 2.8 & 2.9 & 2.8 & Baik \\
\hline Merumuskan/ merencanakan solusi alternatif & 3.01 & 3.22 & 3.39 & 3.21 & $\begin{array}{l}\text { Sangat } \\
\text { Baik }\end{array}$ \\
\hline $\begin{array}{l}\text { Menentukan dan menerapkan strategi/solusi } \\
\text { pemecahan }\end{array}$ & 2.82 & 2.8 & 3.17 & 2.93 & Baik \\
\hline Mengevaluasi & 3.1 & 2.9 & 3 & 3.00 & Baik \\
\hline
\end{tabular}


Pengukuran keterampilan pemecahan masalah dalam ketiga pertemuan dapat terlihat pada Gambar 1.

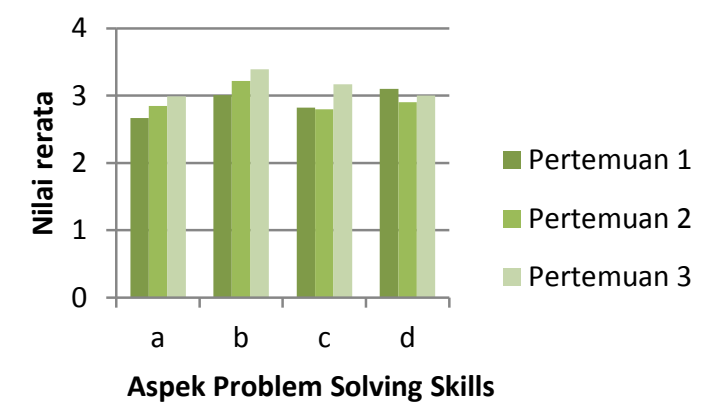

Keterangan:

a. Memahami dan mendefinisikan permasalahan

b. Merumuskan/ merencanakan solusi alternative

c. Menentukan dan menerapkan strategi/solusi pemecahan

d. Mengevaluasi

Gambar 1. Rerata Nilai Keterampilan pemecahan masalah Ketiga Pertemuan

Mengacu pada Gambar 1 dapat diketahui bahwa secara umum terjadi peningkatan aspek keterampilan pemecahan masalah pada setiap pertemuan. Hal tersebut sesuai dengan penjelasan Dewey dalam Akinoglu (2008, p.2) yang menyatakan bahwa pembelajaran aktif dalam kegiatan proyek adalah salah satu kegiatan pendidikan yang dapat membawa peserta didik untuk dapat belajar memecahkan suatu permasalahan sendiri setelah diterapkannya kegiatan proyek dalam pembelajaran di sekolah milik Dewey. Hal ini yang mendasari bahwa penilaian berbasis proyek atau penilaian proyek merupakan salah satu penilaian yang memacu peserta didik keranah berpikir tingkat tinggi salah satunya yakni keterampilan pemecahan masalah. Peningkatan pada setiap pertemuan terjadi pada aspek memahami dan mendefinisikan permasalahan serta aspek merumuskan/ merencanakan solusi alternatif. Aspek menentukan dan menerapkan strategi/solusi pemecahan dan aspek mengevaluasi mengalami penurunan pada pertemuan kedua kemudian mengalami peningkatan pada pertemuan yang ketiga. Peningkatan dan penurunan aspek keterampilan pemecahan masalah terjadi dikarenakan berbagai sebab yaitu tingkatan materi ajar, tingkatan kegiatan proyek yang dilakukan, dan kemampuan dari setiap peserta didik yang mempunyai kondisi yang berbeda.

Peningkatan bertahap yang terjadi pada sebagai besar aspek keterampilan pemecahan masalah setiap pertemuan dikarenakan kemam- puan peserta didik yang mulai terbiasa melakukan kegiatan proyek dengan model discovery learning. Hal tersebut sejalan dengan penelitian Sulistyowati, Widodo, \& Sumarni (2012) yang menyimpulkan bahwa penerapan model pembelajaran discovery learning efektif terhadap kemampuan pemecahan masalah. Kendala yang dihadapi pada pertemuan pertama adalah peserta didik kesulitan dalam merumuskan masalah dan merancang strategi/solusi alternatif sehingga pada tahapan ini guru membimbing setiap kelompok. Pertemuan kedua dan ketiga peserta didik menjadi terbiasa dengan kegiatan proyek sehingga terlihat adanya peningkatan nilai pada hasil kerja peserta didik dalam LKPD yang telah disediakan

Penurunan yang terjadi pada aspek menentukan dan menerapkan strategi/ solusi alternative pada pertemuan kedua dikarenakan waktu yang kurang dioptimalkan dengan baik oleh peserta didik. Penyelesaian kegiatan proyek dikerjakan lebih lama dari waktu yang ditentukan. Selain itu, penurunan yang terjadi pada aspek mengevaluasi dikarenakan sub materi pada pembuatan periskop dan pembuatan mikroskop sederhana yang lebih sulit dibandingkan pembentukan bayangan pada mata manusia sehingga mempengaruhi nilai pada pertemuan tersebut.

Kepraktisan instrumen penilaian yang dikembangkan diperoleh dari data hasil analisis angket. Hasil analisis angket menunjukkan bahwa pada seluruh aspek memiliki kategori yang sangat baik. Dengan demikian, instrumen penilaian proyek keterampilan pemecahan masalah praktis untuk digunakan sebagai alat penilaian.

\section{SIMPULAN}

Berdasarkan hasil penelitian dan analisis data dapat disimpulkan bahwa Instrumen penilaian proyek untuk mengukur keterampilan pemecahan masalah pembelajaran IPA dengan model discovery learning pada materi optik pada mata manusia hasil pengembangan telah layak digunakan karena memenuhi validitas secara isi menurut ahli materi, ahli evaluasi, dan praktisi pembelajaran IPA. Pengujian secara empirik juga membuktikan bahwa instrumen ini dapat digunakan dalam pembelajaran dan menghasilkan reliabilitas yang baik.Para pendidik IPA SMP/MTs dapat mengaplikasikan produk akhir instrumen penilaian proyek untuk mengukur keterampilan pemecahan masalah pembelajaran IPA dengan model discovery learning 
materi optik pada mata manusia pada kelas lain atau pada tahun berikutnya

\section{DAFTAR PUSTAKA}

Aiken, L. (1985). Three coefficients for analyzing the reliability and validity of rating. Educational and Psycological

Akinoglu, O. (2008). Assessment of the inquirybased project implementation process in science education upon students' points of views. International Journal of Instruction, 1, 1-12.Psychological Measurement, 45, 131-142.

Azwar, S. (2014). Penyusunan skala psikologi. Yogyakarta: Pustaka Pelajar

Brookhart, S. M. (2014). How to design question and tasks to assess student thinking. Alexandria: ASCD Publication.

Callison, D. (1998). Authentic assessment. School Library Media Activities Monthly, $5,1-4$.

Castronova, J. A. (2002). Discovery learning for the $21^{\text {st }}$ century: what is it and how does it compare to traditional learning in effectiveness in the $21^{\text {st }}$ century? Castronova Literature, 1, 1-12.

Champine, S. L., Duffy, S.M.,\& Perkins, J.R. (2009). Jerome S. Bruner"s discovery learning model. .Light Bounces Lesson, 1, $1-28$.

Heng, Y.C., Joo, C.E., Basri, A.A.M., Leng, H.H., Bari, N.A., Suleiman, R., Som, A.M., Mustafa, S., Mohamed, S.H.O, Yusof, Z.M., Yazid, Z., \& Majid, Z.A. (2002). Integrated curriculum for secondary school (curriculum specification. science form 2). Kuala Lumpur: Ministry of Education Malaysia.

Hewitt, P.G, Lyons, S, Suchoki, J \&Yeh, J. (2007). Conceptual integrated science. San Francisco: Pearson Education, Inc., publishing as Addison Wesley.

Mardapi, D. (2008). Pengukuran, penilaian, \& evaluasi. Yogyakarta: Nuha Medika

Majid, A. (2014). Penilaian autentik: Proses dan hasil belajar. Bandung: PT Remaja Rosdakarya
Moon, T.R., Brighton, C.M., \& Callahan, C.M. (2005). Development of authentic assessments for the middle school classroom [Versi elektronik]. The Journal of Secondary Gifted Education, 16,119133.

Mueller, J. (2006). The authentic assessment toolbox: enhancing students learning through online faculty development. Journal Online Learning and Teaching ,1.

Muijs, D \& Reynolds, D. (2011). Effective teaching evidence and practice.London: SAGE Publication Ltd

Tivani, I., \& Paidi, P. (2016). Pengembangan LKS biologi berbasis masalah untuk meningkatkan kemampuan pemecahan masalah dan karakter peduli lingkungan. Jurnal Inovasi Pendidikan IPA, 2(1), 35-45. doi:http://dx.doi.org/10.21831/jipi.v2i1.88 04

Shalin, H. (2012). Construction self-discovery learning spaces online: scaffolding and decicion making technologies. USA: IGI Global

Shariff, S. M., Johan, Z. J., \& Jamil, N. A. (2013). Assessment of project management skills and learning outcomes in students' projects. Procedia Social and Behavioral Sciences 90(2013)745-754.

Stiggins, R. J., (1994). Student-centered classroom assessment. New York: Merrill, an imprint of Macmillan College Publishing Company.

Sugiyono. (2012). Metode penelitian kuantitatif, kualitatif, dan $R \& D$. Bandung: Alfabeta.

Sulistyowati, N., Widodo, A.T., \& Sumarni, W. (2012). Efektivitas model pembelajaran guided discovery learning terhadap kemampuan pemecahan masalah kimia. Chemistry in education, 1, 1-7.

Trefil, J \& Hanzen, M.R. (2000). The an integrated approach $5 E$ sciences. NewYork: Jhon Wiley \& Sons, Inc

Widoyoko, E. P. (2009). Penilaian hasil pembelajaran di sekolah. Yogyakarta: Pustaka Pelajar. 